\title{
HOW CAN THE AVIATION SECTOR SURVIVE AFTER COVID-19?
}

\author{
Doaa Salman, Dina Seiam, and Eman Fayaz
}

\begin{abstract}
This paper aims to analyse the adaptation of the airline industry after the hit of coronavirus pandemic. This virus is affecting the global economy by targeting the most profitable industries and making them collapse. By making a qualitative analysis of the topic, this research paper examines how the airline industry faces such a challenge. Also, it analyses how several airline companies shut down through the huge debt that they faced and how tourism declined sharply in all countries. This paper also examines the slow comeback which was experienced by the airline industry. Finally, the paper proposes a set of policies to overcome the current crisis and future setbacks.
\end{abstract}

Keywords: coronavirus, pandemic, aviation, industry, tourism, problem, qualitative JEL Classification: G28, K2, L93

\section{Authors:}

\section{Doaa Salman}

October University for Modern Sciences and Arts, Cairo, Egypt

E-mail:dsalman@msa.eun.eg

https://orcid.org/0000-0001-8276-0959

\section{Dina Seiam}

October University for Modern Sciences and Arts, Cairo, Egypt

E-mail:dinaseiam@gmail.com

https://orcid.org/0000-0002-0204-6753

\section{Eman Fayaz}

October University for Modern Sciences and Arts, Cairo, Egypt

E-mail: Eman.yasser1@msa.eun.eg

https://orcid.org/0000-0002-4399-0249

Citation: Salman, D., Seiam, D., \& Fayaz, E. (2020). How Can the Aviation Sector Survive after COVID19? Virtual Economics, 3(4), 91-105. https://doi.org/10.34021/ve.2020.03.04(5) 


\section{Introduction}

Viruses pose a serious threat to human health. They have caused far more deaths over the last century than all military wars during the time. Influenza was responsible for about 100 million deaths, most of them after the major epidemic of 1918-1919, known as the Spanish flu, as well as the HIV which caused around 30 million deaths. In the year of 2020, there is a new virus causing the death of thousands of people known as COVID-19. Since its first appearance in China at the beginning of the year, the current coronavirus (Covid-19) has spread to almost every country in the world. There has been reported infection among over 2 million people and over 134,000 deaths (Gulland, 2020).

Such kind of viruses causes a serious damage to the society, both to health and economy. The economy in China was the first to be shut down by the coronavirus transmission; however, when it spread through Europe and America, countries all over the world took dramatic measures to seek and curb it. Businesses and banks were closed and residents were restricted to their houses. Standard economic processes were disrupted in peacetime to an unparalleled degree, as daily life habits changed. Governments were taking steps trying to keep businesses afloat and livelihoods from being threatened. Most analysts conclude that the economy has already reached a recession. The global effects of the pandemic promise to be one of the worst disruptions in decades (Bernard, 2020).

The aviation industry is currently fighting for survival and avoiding bankruptcy. This introduction overviews the aviation industry's strategy to cope with the current pandemic from an economic perspective. The pandemic cleared the sky from airplanes landing them on the ground with empty flights. This fact is the main reason behind this research analyzing the impact of this virus on the airline industry, losing billions of dollars of global revenues, and this impact was expected to continue growing if the virus is not controlled.

Many airlines cut capacity and took emergency measures to cut costs. Governments need to take notice as airlines are making every effort to stay afloat as they perform the vital task of linking the economies of the world. As governments targets to stimulus measures via consideration for tax relief, charges and slot allocation will be required for the airline industry, if not, it is expected to file bankruptcy which is not favorable for the country's economy since most airlines are currently striving desperately to preserve cash and many are asking or forcing staff to take unpaid leave, in addition to cutting flights.

The research is divided into different sections as we start with a literature review that discusses three points: first is the pandemic, second is an externality, and the third point is the types of externality. Then, we could see how different countries are affected by airlines like Flybe, Trans States Airlines, and Compass airlines. Moreover, the effect on tourism will be elaborated. Eventually, the research is ended with future expectations of what may happen in the airline industry after the end of the pandemic.

Doaa Salman, Dina Seiam, and Eman Fayaz

Virtual Economics, Vol. 3, No. 4, 2020 


\section{The Literature Review}

Pandemic is a disease outbreak that has spread through a wide area, such as several countries, or across the globe. Externality applies to a loss or benefit (spill-out) paid or earned by a third party. The third-party, however, does not influence the development of the expense or benefit. Externality may be either positive or negative and may result either from the manufacture or consumption of a good or service. Breakdowns are the subject of a broad analysis outside of any financial activity. Besides, externalities emerge from the decisions that individuals and firms make in civil society and on the markets. Economic measures, such as disease prevention, can create externalities and unexpected effects (Fisman \& Laupland, 2009).

The disease is a pandemic and can affect the economies of the country due to its widespread. Besides, we can see that the COVID-19 is causing different externalities from a pandemic; these externalities can be either positive or negative. The negative externalities that can be illustrated by panic buying in supermarkets, people after knowing the dangers of the virus they rushed to the supermarkets and emptied its shelves like toilet papers, essential goods, masks, and hand sanitizers without giving other people chances to purchase, and that can lead to an increase in the commodity prices. The panic buying is irrational because buying more and more will not solve the panic. Panic purchasing during the crisis can push costs up and get essential commodities out of people's hands that need them most (e.g. health workers' face masks) (Lufkin, 2020). Another negative externality is the macroeconomic fall-out since there is a lock-down: factories are unable to produce, which caused many individuals to lose their jobs, or cut-out their incomes since there is no productivity. Here the country faces different problems which will result in the rise in government debts and cause tax burden on companies in the future. Also, social behaviors that spread infection is a negative externality, when citizens don't follow the guidelines of preventing the spread of the disease like social distancing, wearing masks, washing hands, etc. that causes an increase in the number of cases.

On the other hand, there are positive externalities like the decline in pollution due to the lockdown: the factories, schools, malls are closed, so output slowed down company operations and limited transportation that result in lower $\mathrm{CO}_{2}$ and $\mathrm{NO}_{2}$ emissions and cleaner oceans. China is one of the most polluted countries, yet current satellite images indicate a drastic decrease in pollution rates in China, also NASA maps display a drop in nitrogen dioxide $\left(\mathrm{NO}_{2}\right)$ levels relative to the first 2 months of 2019 (Okyere et al., 2020). Moreover, in Italy, the canal water in Venice became clean, first in a very long time, and dolphins started showing up. An additional positive externality is the development of technology as a result of social distancing at schools and universities around the country.

Good health and quality of life are perceived to be a global and jointly associated life commodity, which ensures that economic and health growth interrelates into a fundamental driver for sustainable economic development. Several researchers have demonstrated that building a healthy community is a permanent benefit for the growth of society and economic growth. Several related studies have been undertaken over recent years by different 
academics to draw public and private sector's attention to the effect of health care and climate on economic growth and whether the government can achieve sustained economic growth mainly during the times of health crisis (Alhassan et al., 2020). Due to Covid-19, countries face a decline in economic growth, but what differentiates one country from another is the health expenditure. When the nation has advanced health care, it will be able to control the disease more than a country that doesn't have one.

Tourism is also one of the main aspects that control the economic growth. The top four countries that are reliant on tourism are Mexico, Spain, Italy and Turkey. Tourism is one of the world's biggest businesses and one of economic activity's fastest growing industries. Several studies have shown the long-term impact of economic development on tourism, also numerous developing nations view tourism as a big part of economic growth and sustainability policies, as a source of limited financial services, employment, foreign currency profits and technological aid (Akan et al., 2007).

\section{Research Methodology}

This study is an exploratory conclusive research design since there are cause and effect relations that seek to achieve better understanding of COVID-19's current situation in the aviation industry to reveal new concepts and perspectives. A more detailed understanding of certain areas of the topic has been demonstrated. This article relies on qualitative proof regarding conclusions and the usage of secondary data derived from prior scientific articles.

\section{The Impact of COVID-19 on the World Airline Industry}

Contribution of the travel and tourism sector in the direct GDP growth rate is $10.2 \%$, which represents USD 7.6 trillion. For instance, during one year the GDP for travel and tourism increased from 3.1\% in 2016 to 3.85\% in 2017. This sector during 2016 provided 292 million equivalent jobs. Moreover, $6.6 \%$ of total world exports and almost $30 \%$ of total world exports of services are represented by this sector (UNWTO, 2020). However, the COVID-19 outbreak has had a negative influence on the aviation sector in many respects. The demand for travel to Asia from the rest of the world plunged almost as soon as the news of the virus became viral in late January. Just before conservation across the globe was implemented, airlines began dramatically cutting flights to China, and other Asian destinations as COVID-19-related fears and worries led travelers to avoid traveling to the area. However, it became clear within weeks that routes to Asia were not the only flights to deal with lower demands. When the epidemic extended to Europe, followed by America and Africa, demand for travelers plunged worldwide. One was doubting trips away from home and sought to prevent anything requiring air travel, despite the space given between each seat, people found it risky to fly (Business Insider, 2020).

\subsection{An Overview of the Impact on the Aviation Market}

Doaa Salman, Dina Seiam, and Eman Fayaz

Virtual Economics, Vol. 3, No. 4, 2020 
In December 2019, after the United States and the United Kingdom, China was considered the world's third-largest aviation market, but four weeks after the beginning of the January 2020 outbreak, China's ranking fell to 25th place. The coronavirus undoubtedly had a significant effect on airline activities, thus, on global aviation supply and demand, with many flights canceled either by the airline itself or as a result of the authorities shutting airports or roads (Mhalla, 2020).

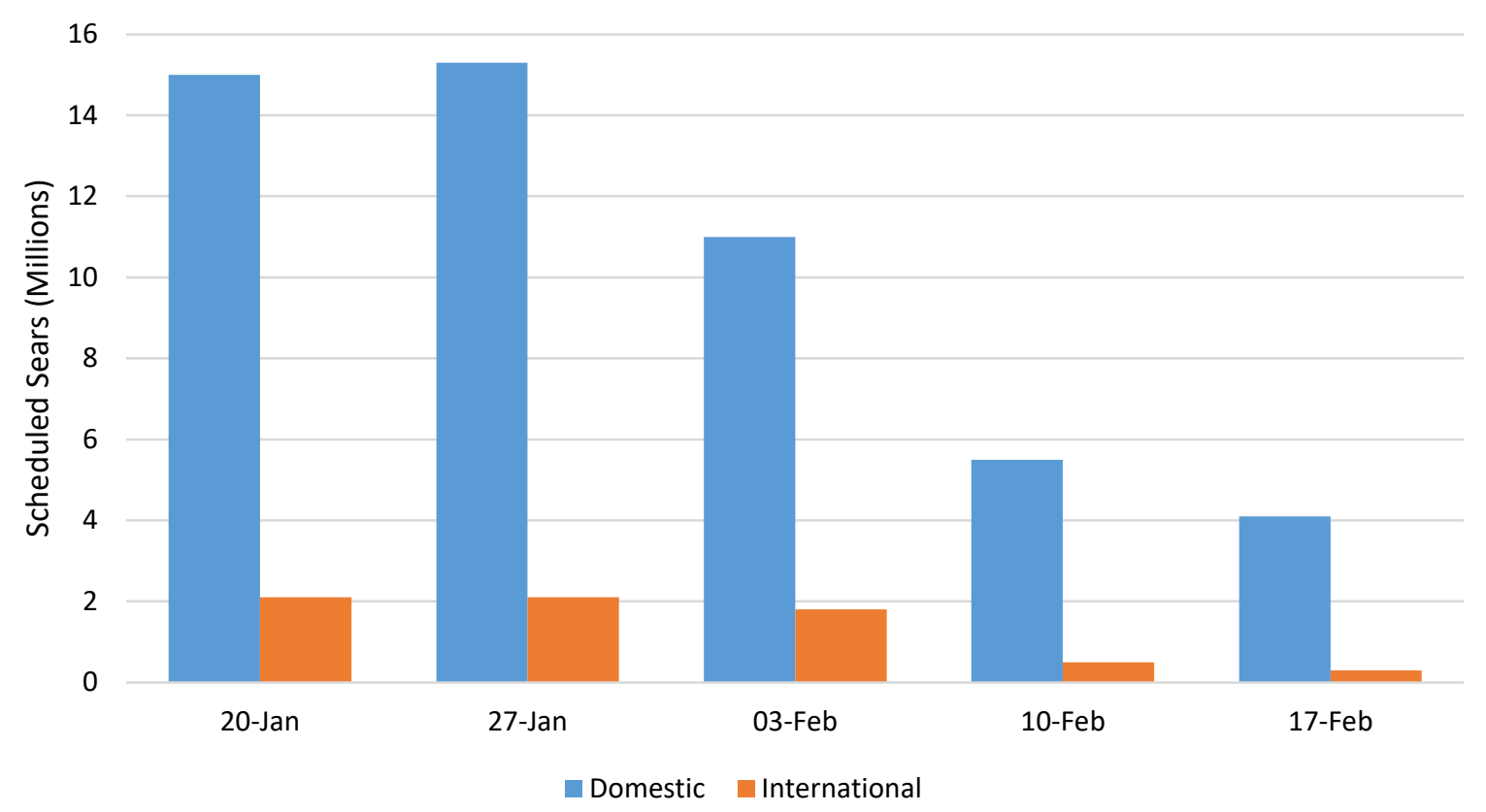

Figure 1. The Number of International and Domestic Seats Operated within and from China. Source: OAG schedules analyzer, 2020.

The above figure shows the number of weekly international seats that operated from China has fallen to 1.7 million seats, which is an $80 \%$ reduction. While the domestic Chinese market saw 10.4 million fewer seats operated.

According to the Official Airline Guide (OAG), a global source of travel information, the top three Asian countries that have been greatly affected by the coronavirus outbreak are Japan, the first market for Chinese travelers to record a decrease in scheduled airline ability of more than 200,000 seats a week relative to the week of 20 January, a decline of 74.6 percent in four weeks. Thailand is the second as a country that greatly benefits Chinese travelers, particularly tourists visiting the country, reported a drop in ability of more than $76 \%$ between 20 January and 17 February, and the third is South Korea, which also reported a sharp drop of more than $69 \%$ in its airline capacity.

Other major countries have recorded, as the same source states (OAG) that there has also been a dramatic reduction of capacity over the four weeks, including Indonesia (92 percent), Singapore (-89 percent), Hong Kong (SAR) China ( 80 percent) and the USA (-86 percent). The ban policies of some countries also did not represent explicitly such capabilities as Italy, 
although the magnitude of the effect was highlighted by the direct air links to other markets such as Hungary, Oman, and Maldives (Mhalla, 2020).

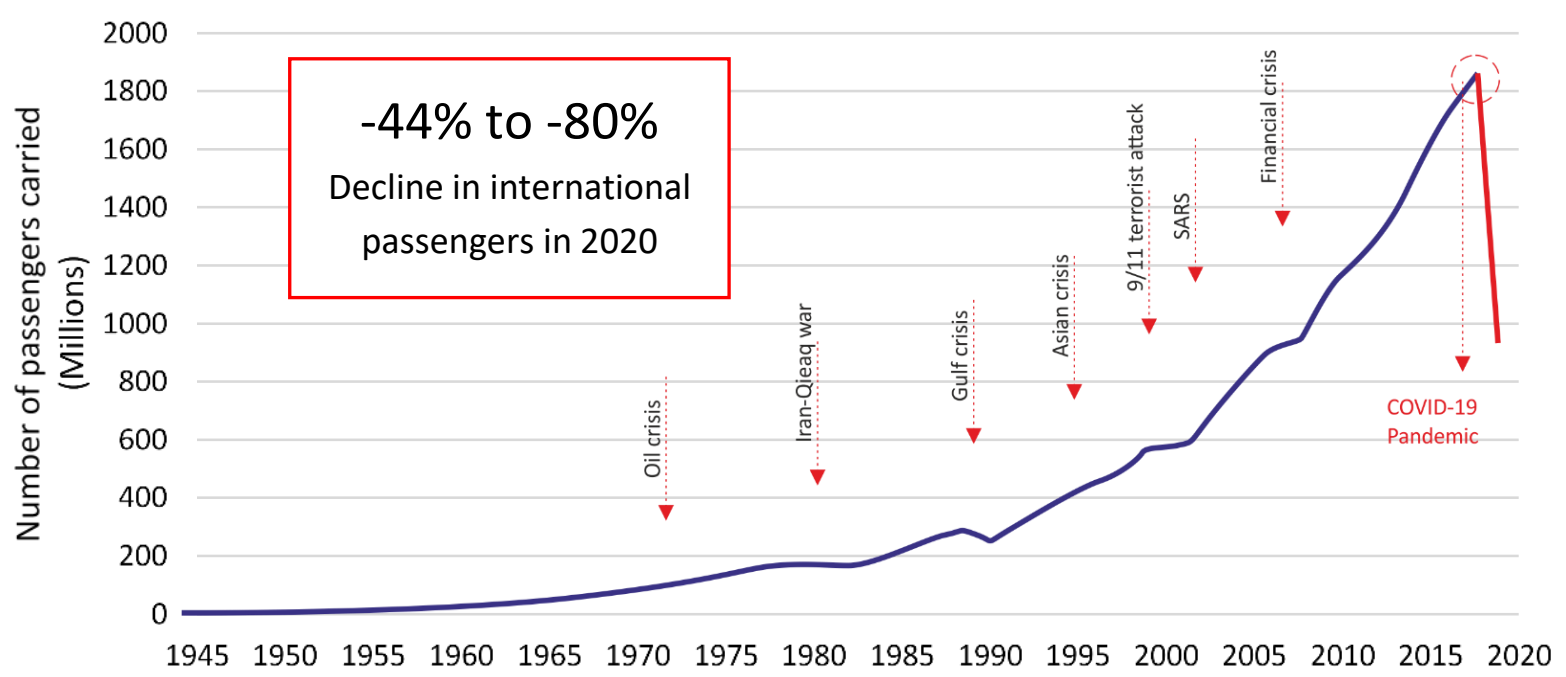

Figure 2: The International Traffic Collapse: An Unprecedented Decline in History Source: ICAO Air Transport, 2020.

According to the ICAO (2020), the consequences of the COVID-19 pandemic is way larger than the impacts observed during the SARS epidemic that was in 2003 this is because of two main reasons: the first reason is that since 2003, China's overall air traffic weight from and to the country has doubled, and on the other hand, the domestic flights have decreased. The second reason is that air traffic dropped substantially ever since 70 airlines canceled their long haul flights. The total number of Chinese carriers has been reduced by $40 \%$. The ICAO also illustrated that until the spread of the COVID-19 outbreak, the affected airlines expected to increase the capacity to and from China by $9 \%$ in the first quarter of 2020 compared to the same time-frame in 2019. However, this was not the case due to the outbreak; a decision was made to reduce the airline capacity, in which no less than 16.4 to 19.6 million travelers would potentially miss the call. This significant capacity reduction would lead to an overall loss of gross revenue of $\$ 4$ billion to $\$ 5$ billion.

The spread of the pandemic will also have a negative impact on the profitability and the cash flows of the airlines, due to the cancellations; this could cause the airlines' massive sums of money in terms of lost income and operating expenses and would deprive certain sectors of the travel industry, particularly hotels and retailers (Mhalla, 2020).

\subsection{The Impact on International Airline Companies}

The International Air Transport Association (IATA) announced that the estimated global airline industry sales losses are predicted to hit around 250 billion US\$ in 2020, up from the previous forecast of 113 billion US\$. The sharp rise in the forecast of losses comes with more and more 
countries closing their borders to global airlines. In addition, IATA officials said that the recovery of the global aviation industry is unlikely to come soon because the world has never seen a pandemic correlate with a global recession (Bureau, 2020).

In Europe and America, regulatory laws allow airlines to refund costs when flights are canceled, but instead, airlines have provided vouchers or travel credits, in certain cases, that are expected to be used by the year-end. (May 2022 was extended by other airlines via voucher window). Generally, vouchers are available if travelers change travel arrangements due to flight alerts, residency orders, and other limitations (Schaper, 2020). In March 2020, the British airline Flybe crashed as a result of the recent coronavirus outbreak that gave the carrier its final blow. The airline has been failing for quite a time. The UK government announced in January that its finances were being debated and rescreening options were being examined, adding that the Flybe management and its shareholders were putting the airline "on the road to recovery," but Flybe was "complemented by a coronavirus outbreak that had a serious impact on the market in recent days," said the airline. Although Flybe was on the verge of failure, despite big investment from a Consortium caused by Virgin Atlantic the last summer, the crash of the coronavirus forced Flybe over. About $40 \%$ of UK domestic flights were run by Flybe. In addition, the UK Transportation Department announced that it would help Flybe workers "as soon as possible" look for new jobs, and Loganair, a Scottish airline, announced that it will take more than 16 flight routes and that over the next four months, flights would be launched in phases (Toh, 2020).

Multiple airlines suspended penalties for flight booking modifications and cancelations after the coronavirus epidemic following an appeal by Sen. Richard Blumenthal. Between the $20^{\text {th }}$ of January and the $7^{\text {th }}$ of March 2020, the US airline stock prices decreased by $30 \%$. Flight prices for domestic flights have also fallen. On 25 March, the US Senate passed a bill offering $\$ 58$ billion in loans and grants to aviation-related businesses, including \$25 billion for passenger carriers and $\$ 4$ billion for freight carriers, plus $\$ 17$ billion for businesses "essential to preserve national security" such as Boeing. Airlines accepting the package should be restricted from raising executive pay, offering dividends, or purchasing back shares over the assist era (Slotnick, 2020a). Trans States Airlines is a regional airline from Missouri that operates under the United Express name on routes to the United States. The airline is expected to close its operations with ExpressJet Airlines, another regional airline in the United States, by the end of 2020. Compass Airlines, a regional carrier operating in the US and Delta, said that demand is collapsing as some of the first job cuts in U.S. airlines are occurring in the crisis of the coronavirus. Airlines struggle to save money and are cutting their networks drastically while seeking government assistance of more than $\$ 50$ billion. Trans States Airlines, told employees that it would move a scheduled closing of its eponymous airline up to April 1 (Josephs, 2020).

On the $21^{\text {st }}$ of April, Virgin Australia, Australia's bankruptcy counterpart, entered "volunteer administration." Although Brisbane's most operations were suspended and employees were flooded, the airline continued to lose money on about 65 day-to-day flights. In the 
restructuring process, the airline said it would continue working. After an appeal for aid from the Australian Government was denied, it entered the administration (Slotnick, 2020b).

Accords with the interview by Allan Kilavuka, Kenya Airways Interim President and CEO at The EastAfrican, Kenya weekly newspaper The Coronavirus outbreak (COVID-19) is going to constitute a big income blow to Kenya Airways (KQ), even began to take action to minimize their economic losses. The company anticipates a revenue loss of approximately $\$ 8$ million for both passengers and freight. The Israeli national corporation El Al also reported last week that it will be willing to cut 1,000 of its 6,000 workers and that its expenses would be between $\$ 50$ million and $\$ 70$ million for the first quarter alone. Losses that may lead the organization to decline dramatically. Air Canada reports, however, that 5,100 airlines are temporarily employed and would cancel most of its international flights, including Finnair, Norwegian Air, Westjet, and many others, but they are confronted by several difficulties and are trying to find out how to keep them laying off workers in the market (Mhalla, 2020).

\subsection{Tourism Shock}

Tourism is considered one of the most quickly expanding sectors to be vulnerable, i.e. tourism is influenced by any external or internal unexpectedness or tension in contrast to other industries. The new Corona (COVID-19) epidemic has triggered disasters in the entire world in this relation. A significant influence on the tourism industry is being exerted by the COVID-19 pandemic and steps introduced to restrict its spread.

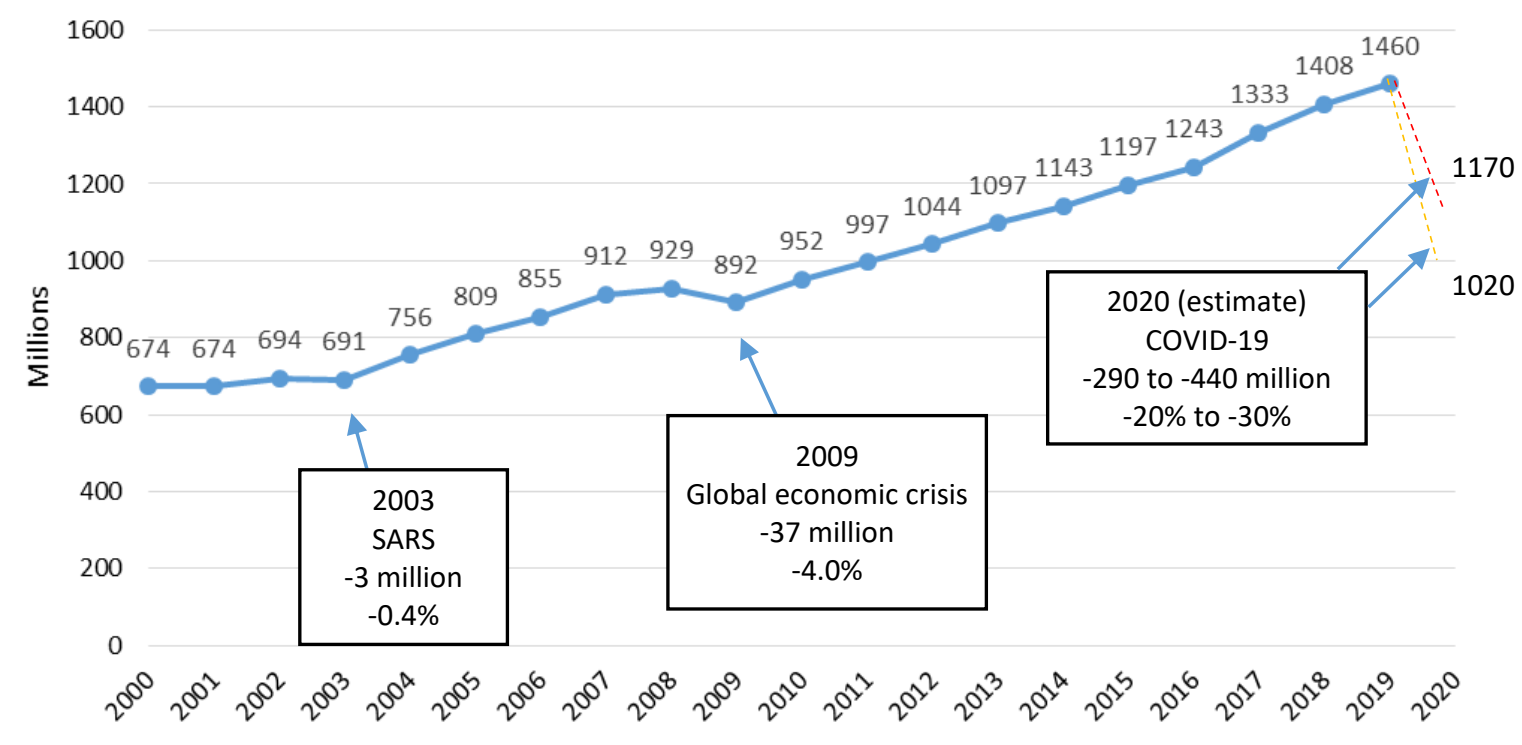

Figure 3. The 2020 Forecast - International Tourist Arrivals, World (millions) Source: (UNWTO, 2020). 
According to the United Nations World Tourism Organization (UNWTO), the COVID-19 pandemic will result in a contraction of the tourism sector by $20 \%$ to $30 \%$ in 2020 . This estimate is likely to be conservative for countries relying on foreign tourists, as the recent data on daily air traffic indicate a drop of almost $80 \%$ since January 2020 . Although certain economic industries will rebound after draconian controls have been abolished, this pandemic may have a longer-term impact on international tourism. This is partly due to lower consumer morale and the possibility that the free movement of people will be more limited. According to the WTTC, the estimated time of rehabilitation for travelers to a destination in past viral epidemics was around 19 months (Hamilton, 2020).

Obviously, all the countries are affected negatively by the pandemic that results in travel restrictions. Every country is trying to control the virus by canceling flights in order to control the number of cases, but that affected the economy significantly. In this section, we will discuss the situation in several countries facing numerous problems due to temporarily suspension of all international flights. Approximately two-thirds of international flights to and from China were scrapped in February 2020. Flights between Japan and China saw a $60 \%$ decrease in traffic, while the US and China saw a decrease of $86 \%$. Two-thirds of domestic flights inside China were likewise canceled, accounting for about 10,000 flights a day, while ticket prices for the remaining flights decreased - the South China Morning Post announced a three-hour flight seat between Shanghai and Chongqing rate. Passenger traffic fell by $75 \%$ between January 25 and February 14 relative to the same time in 2019 (Lee, 2020). It is reported that Indian airlines are reporting USD 600 million losses in the period January-March (not including state-owned Air Index). The Government of India is considering a bailout package for the aviation industry amounting to INR 120 billion (USD 1.6 billion) (Reuters, 2020).

\section{Future Expectations}

First, COVID-19 seemed like past crises: traffic and sales strike followed by a return to normal, even though there was confusion about the magnitude and length of the impact. The decline in sales suffered by airlines this year as a result of COVID-19 significantly exceeds the effects of previous crises. It has got the characteristics of a civil war. Moreover, the next recession is expected in 2020/21, which means that the rebound will take longer. Moreover, even after healing, 'natural' is not going to be the same as before. There are expected to be permanent effects on the air travel market. As a result of lockdowns, or close lockdowns, around the world, people are increasingly finding new ways to live their lives, both at work and leisure. More than ever before, technology is becoming a more practical and more commonly used alternative to commercial air travel.

\subsection{An Estimated Impact on the International Passenger Traffic and Revenues}

The figure below shows how deeply the COVID-19 epidemic will influence regions' capability, passengers, and revenues in 2020. According to the ICAO estimates (2020), it is anticipated that North America will reduce its capacity from $33 \%$ to $65 \%$, drop in the number of passengers 
will significantly decrease from 65 million to 120 million, and the loss of revenues will increase from US\$17 billion to US\$32 billion.

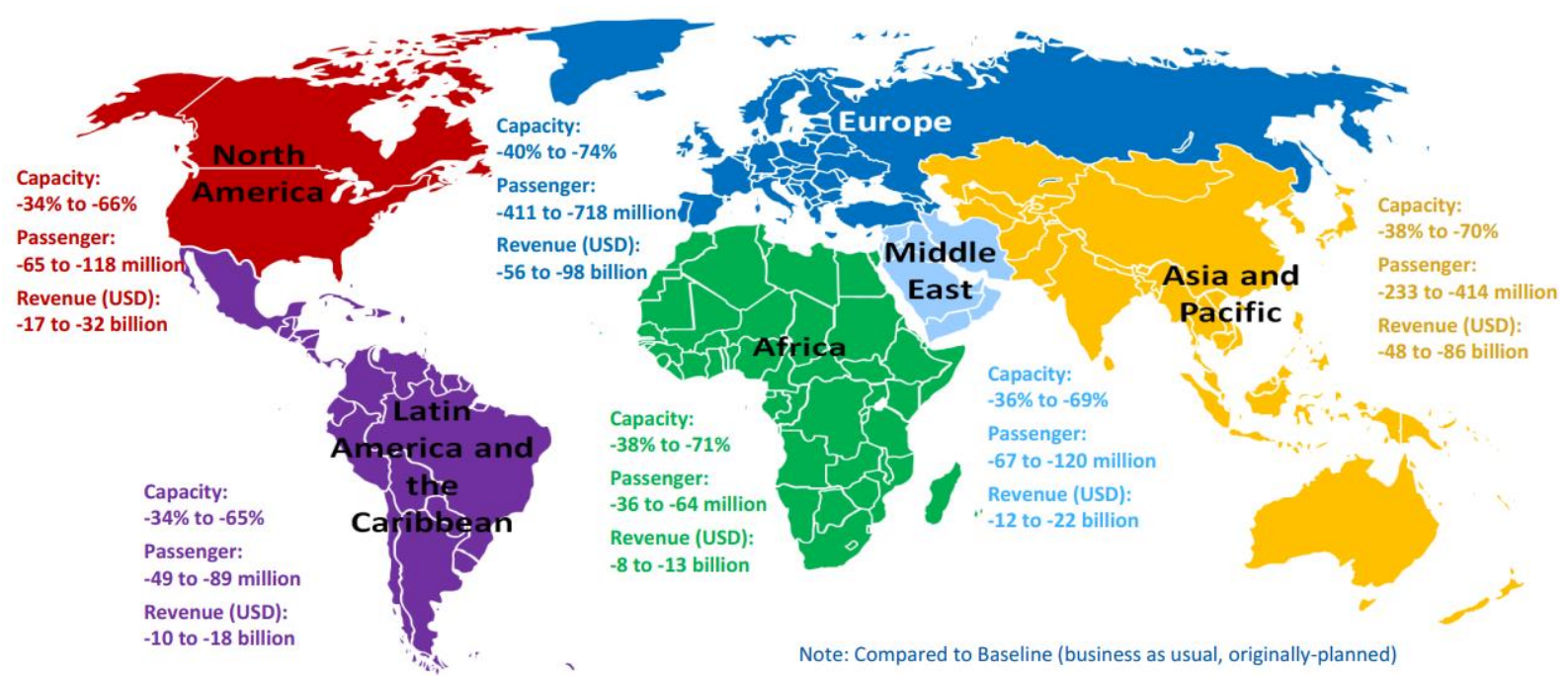

Figure 4. The Estimated Effect on the International Traffic and Revenues by Region for 2020 Source: ICAO estimates, 2020.

It is anticipated that Latin America and the Caribbean will reduce their capacity from 35 percent to 65 percent, passengers are estimated to drop from 50 million to 90 million, and revenues are estimated to decline from $\$ 10$ billion to $\$ 18$ billion. While Europe's airline capacity is projected to decline by 419 to 731 million, and revenues are estimated to go down by $\$ 57$ billion to $\$ 101$ billion. It is expected that the airline capacity in Africa will decrease by 34 million to 61 million travelers, and revenues will drop by $\$ 7$ billion to $\$ 13$ billion. The Middle East airline's capacity is estimated to decline by $37 \%$ to make up $70 \%$, as a result, passengers will drop by 66 million to 119 million people, and the revenues' loss will range from $\$ 12$ billion to $\$ 22$ billion. Finally, the airline capacity of Asia and the Pacific will be reduced by $39 \%$ to reach 715, the number of passengers will decrease from 238 million to 420 million people and the revenues will decrease by $\$ 50$ billion to account for $\$ 88$ billion.

\subsection{The Expected Global Impact on Aviation, Tourism, Trade, and Economy}

- International air passenger traffic might deal with an average decline in the international passengers from 44\% to 80\% in 2020 compared with 2019 (ICAO, 2020).

- Airports may experience an expected loss of two-fifths of passengers carried and $45 \%$ or more than \$76 billion of airport revenues in 2020 (ICAO, 2020).

- Tourism may face a decrease in international tourism industry receipts between about $\$ 300$ billion and $\$ 450$ billion in 2020, nearly $1 / 3$ of the $\$ 1.5$ trillion created in 2019 , with travel restrictions of 96 percent of world destinations (ICAO, 2020).

- Trade may have a decrease in the amount of global trade in goods by $13 \%$ to $32 \%$ in 2020 compared to the previous year (WHO, 2020). 
- Global economy may have to cope with a predicted 3 percent fall in the global GDP in 2020 , much greater than in the financial crisis of 2008-2009 (IMF, 2020).

\subsection{Expected Travel-Related Losses in the US 2020}

- Travel industry losses: $31 \%$ drop is expected throughout 2020, with a $75 \%$ decrease in revenues in the coming months and ongoing losses hitting $\$ 455$ billion for the rest of the year.

- GDP losses: losses from the travel industry will have a cumulative impact on GDP of $\$ 450$ billion in 2020. The US economy is expected to face a recession based on a projected decline in travel alone. The recession will likely last for at least three quarters.

- Tax losses: $\$ 55$ billion reduction in taxes will be recognized as a result of reductions in travel in 2020.

- Employment losses: The United States economy is expected to cut 4.6 million jobs as a consequence of a fall in travel in 2020. The rate of unemployment will naturally increase by $3.5 \%$ in the following months. Over the coming months, travel-related job losses alone could drive the unemployment rate up to 3.6 percent, as shown in Figure 5.

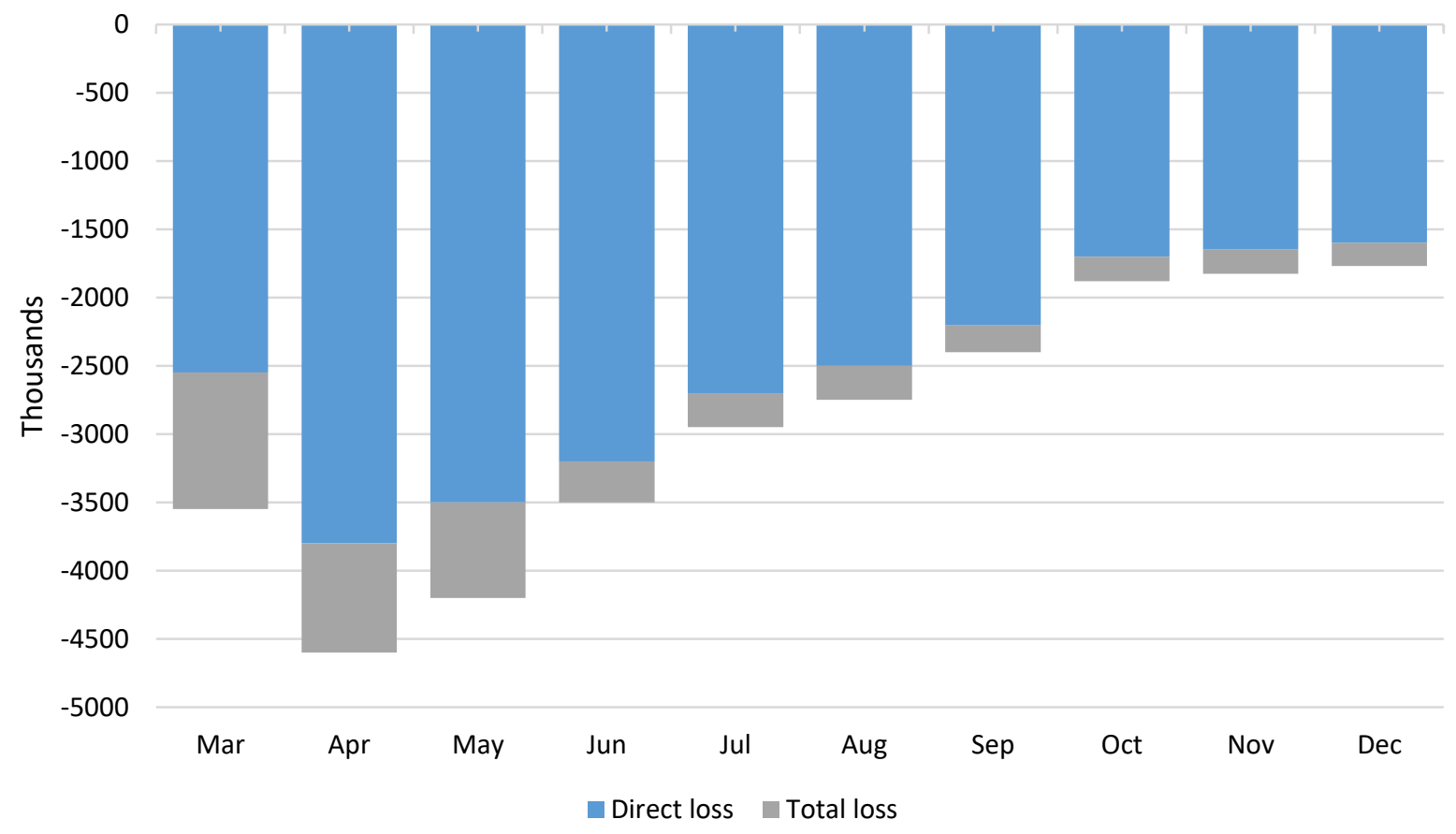

Figure 5. Jobs Losses Expected in the Tourism Industry

Source: Oxford Economics, 2020.

As seen in the figure above, job losses in the tourism industry will increase but will continue with 1.6 million jobs already lost in December for the rest of the year. At the lowest point this year, 4.6 million people will lose their employment as a result of a downturn in tourism, including 3.6 million jobs directly in the travel industry (Oxford Economics, 2020). 


\section{The Travel Industry Recovery}

The travel industry will take a long time to recover or return to its previous levels after the Covid-19 pandemic; however, the recovery will be in stages. The domestic and regional travels are expected to see a comeback before the international travel takes place. According to a survey undertaken by the Global Business Travel Association of its member organizations, businesses are twice as likely to have avoided international travel as domestic travel has been avoided since July 2020. In the case of domestic travel, trips which may take place in personal or rented vehicles may replace short regional flights before the convenience of businesses to send employees by aircraft rises (Curley et al., 2020).

International travel would take longer to recover due to the uncertainty of government restrictions, statutory quarantines, and high likelihood of fast-changing policies. In Asia, some governments (e.g. Malaysia and Singapore) investigate the establishment of business corridors to support economic growth under strict guidelines authorizing exemptions from quarantine measures, (Curley et al., 2020).

\section{Recommendation and Polices}

The COVID-19 epidemic has had and will continue to have a significant effect on the aviation industry in Europe and abroad. The condition is deteriorating every day. In the next few weeks, traffic is expected to drop further. The European Commission will propose tailored regulations to partially exempt airlines from their airport slot use restrictions, under the EU law in order to help mitigate the effects of this pandemic.

Green recovery for the airport sector can only occur as airlines start resuming their services. Nonetheless, in order to do so, nations would first need to remove travel bans and border controls. China claims to be managing the COVID-19 pandemic and opening up its airspace, only to enforce additional limits on foreign flights shortly after that to deter imported incidents. This is possible that domestic air traffic will be the first to restart if a country thinks that its internal situation is relatively stable.

To bring the international air traffic back on its feet there must be confidence that the pandemic is under global control and that traffic is secure. Until an appropriate solution is available, any recovery is required to proceed at a calculated rate.

Besides, applying safety measures and hygiene will be a lifestyle that the whole globe had to apply in order to retain the industry. In order to minimize transmission of diseases beyond COVID-19, airports will seek automated, hands-free, self-processing options for passengers during the flight. Some Common User Self Service (CUSS) market-based approaches now exploit touchless biometrics, such as iris scanning and face recognition. COVID-19 may well be a mechanism that promotes the widespread acceptance of touchless technology. Countries need to apply an immunity passport showing the vaccination from COVID-19 similar to the current measure that is applied in different countries across the globe. 


\section{References}

Akan, Y., Arslan, I., \& Isik, C. (2007). The Impact of Tourism on Economic Growth: The Case of Turkey. Journal of Tourism, 9(1), 1-24.

Alhassan, G. N., Adedoyin, F. F., Bekun, F. V., \& Agabo, T. J. (2020). Does Life Expectancy, Death Rate and Public Health Expenditure Matter in Sustaining Economic Growth under COVID-19: Empirical Evidence from Nigeria? Journal of Public Affairs, e2302. https://doi.org/10.1002/pa.2302

Bernard, S. (2020, April 8). Coronavirus Economic Tracker: Latest Global Fallout. Retrieved from https://www.ft.com/content/0c13755a-6867-11ea-800d-da70cff6e4d3

Bureau, O. (2020, March 24). Global Airline Losses May Hit \$250 b in 2020: IATA. Retrieved from https://www.thehindubusinessline.com/economy/logistics/global-airlinelosses-may-hit-250-b-in2020-iata/article31155911.ece

Business Insider. (2020). What to Know about the Coronavirus Pandemic in 25 Charts and Maps. Retrieved from https://www.businessinsider.com/coronavirus-in-charts-covid-19-symptomsspread-deaths-warnings-2020-2

Curley, A., Garber, R., Krishnan, V., \& Tellez, J. (2020, August 13). For Corporate Travel, a Long Recovery Ahead. Retrieved from https://www.mckinsey.com/industries/travel-logistics-and-transportinfrastructure/our-insights/for-corporate-travel-a-long-recovery-ahead

Fisman, D. N., \& Laupland, K. B. (2009). The Sounds of Silence: Public Goods, Externalities, and the Value of Infectious Disease Control Programs. Retrieved from https://www.ncbi.nlm.nih.gov/pmc/articles/PMC2706405/

Gulland, S. N. A. (2020, April 16). What is Coronavirus, how did it Start and How Big could it Get? Retrieved from https://www.telegraph.co.uk/news/2020/04/16/whatcoronavirus-china-covid-19started/

Hamilton, P. C. (2020, April 24). Impact of COVID-19 on Tourism in Small Island Developing States. Retrieved from https://unctad.org/en/pages/newsdetails.aspx?OriginalVersionID=2341

ICAO. (2020). Retrieved from https://www.icao.int/sustainability/Documents/COVID19/ICAO_Coronavirus_Econ_Impact.pdf

IMF. (2020). Retrieved from https://www.imf.org/en/Topics/imf-and-covid19

Josephs, L. (2020, March 20). Regional US Airline Compass Shutting down as Coronavirus Presents 'Insurmountable Obstacles.' Retrieved from https://www.cnbc.com/2020/03/19/coronavirusprompts-us-regional-us-airline-compassto-shut.html

Lee, A. (2020, February 28). Flight for Less than a Cup of Coffee? China's Airlines Try to Lure Customers. Retrieved from https://www.scmp.com/economy/chinaeconomy/article/3052484/coronavirus-chinas-airlinesoffer-domestic-flights-little-us4 
Lufkin, B. (2020, March 4). Coronavirus: The Psychology of Panic Buying. Retrieved from https://www.bbc.com/worklife/article/20200304-coronavirus-covid-19-update-whypeople-arestockpiling

Mhalla, M. (2020). The Impact of Novel Coronavirus (COVID-19) on the Global Oil and Aviation Markets. Journal of Asian Scientific Research, 10(2), 96.

OAG. (2020). Retrieved from https://www.oag.com/hs-searchresults?term=future+expectation+of+COVID19\%27s+impact+on+aviation+\&type=SITE_PAGE\&type=BLOG_POST\&type=LISTING_PAGE

Okyere, M. A., Forson, R., \& Essel_Gaisey, F. (2020, April 10). Positive Externalities of an Epidemic: The Case of the Coronavirus (COVID_19) in China. Retrieved from https://onlinelibrary.wiley.com/doi/pdf/10.1002/jmv.25830

Oxford Economics. (2020). Retrieved from https://www.ustravel.org/sites/default/files/media_root/document/Coronavirus_2020_Impacts_ WEB.pdf

Reuters. (2020, March 19). India Mulls up to \$1.6 Billion Rescue Plan for Aviation Sector after Coronavirus. Retrieved from https://economictimes.indiatimes.com/industry/transportation/airlines-/-aviation/indiamulls-upto-1-6-billion-rescue-plan-for-aviation-sectoraftercoronavirus/articleshow/74702715.cms?from $=\mathrm{mdr}$

Schaper, D. (2020, April 7). Airlines Want To Cancel Rule Requiring Them To Refund Fares For Canceled Flights. Retrieved from https://www.npr.org/sections/coronavirusliveupdates/2020/04/07/829091394/airlines-want-to-cancel-rule-requiring-them-torefund-fares-forcanceled-flights

Slotnick, D. (2020a, April 21). Many of the World's Airlines could be Bankrupt by May because of the COVID-19 Crisis, according to an Aviation Consultancy. These Airlines have Already Collapsed because of the Pandemic. Retrieved from https://www.businessinsider.com/coronavirus-airlinesthat-failed-bankrupt-covid19pandemic-2020-3\#compass-airlines-us-march-2020-3

Slotnick, D. (2020b, March 27). Airlines will Get the \$60 Billion Bailout They Asked for in the \$2 Trillion Coronavirus Stimulus Bill that Trump Signed into Law. It also prohibits layoffs, stock buybacks, and dividends. Retrieved from https://www.businessinsider.com/airlines-coronavirus-bailout-senatestock-buybacks2020-3?r=US\&IR=T

Toh, M. (2020, March 5). UK Airline Flybe Collapses as Coronavirus Crisis Deals the Final Blow. Retrieved from https://edition.cnn.com/2020/03/04/business/flybe-collapse-2020/index.html

United nation world travel organization - UNWTO. (2020, March 27). World Tourism Organization. Retrieved from https://www.unwto.org/impact-assessment-of-the-covid-19-outbreak-oninternationaltourism 
WHO. Coronavirus. (2020). Retrieved from https://www.who.int/emergencies/diseases/novelcoronavirus-2019 